\title{
Crustal thickening in an active margin setting (Philippines): The whys and the hows
}

National Institute of Geological Sciences, College of Science, University of the Philippines, Diliman, Quezon City, Philippines 1101. E-mail: rwg@i-next.net

A synthesis of crustal thickness estimates was made recently utilizing available field, geochemical, seismicity, shear wave velocity and gravity data in the Philippines. The results show that a significant portion of the Philippine archipelago is generally characterized by crust with a thickness of around 25 to 30 kilometers. However, two zones, which are made up of a thicker crust (from 30 to $65 \mathrm{~km}$ ) have also been delineated. The Luzon Central Cordillera region is characterized by thick crust. Another belt of thickened crust is observed in the Bicol-Negros-Panay-Central Mindanao region. This paper examines the interplay of tectonic and magmatic processes and their role in modifying Philippine arc crust. The processes, which could account for the observed crustal thicknesses, are presented. The contributions of magmatic arcs as compared to the contribution of the emplacement and accretion of ophiolite complexes to crustal thickness are also discussed.

\section{Introduction}

The evolution of continental crust has been a problem of long standing interest to various geoscientists. In studies, which try to address the question of crustal growth, the addition of materials to the crust is attributed to several mechanisms. Juvenile crustal material is produced in island arcs and oceanic plateaus (Rudnick, 1995; Condie, 1998). These features eventually collide with and become sutured to continents thereby leading to the growth of continental crust. Contributions from magmatic underplating and overplating (Wilson, 1994; Rapp and Watson, 1995) as well as from the emplacement of ophiolites have also been recognized (Dewey and Windley, 1981). Processes such as arc magmatism, oceanic plateau accretion, intraplate volcanism, crustal underplating, accretion of ophiolites, sediment subduction, tectonic erosion and delamination may operate singly or in combination to contribute to crustal growth. In the Philippines, relatively few studies have looked closely into the problem of crustal growth. Crustal thickness estimates are limited to specific areas and are mostly derived from geochemical, seismicity, focal mechanism and gravity data (Bautista et al., 2001; Barretto et al., 2000). A recent compilation of geochemical, seismicity and gravity data to estimate crustal thickness in various parts of the Philippines show that a significant portion of the Philippine archipelago is characterized by crust with thicknesses ranging from 15 to $30 \mathrm{~km}$. However, areas underlain by a thicker crust (from 30 to $65 \mathrm{~km}$ ) have also been recognized from a recent compilation (Dimalanta \& Yumul, 2003).

The complex geodynamic and tectonic setting of the Philippines necessitates an understanding of the role of tectonic and magmatic processes to crustal growth. The following questions need to be addressed. How much of the observed crustal thickening in some parts of the Philippines could be attributed to subduction processes? What is the effect of collision events on crustal growth? What other processes contribute to the thickened crust? This paper forwards an explanation on the different mechanisms and processes, which can account for the thickness of crust in the Philippines. This, hopefully, can help in our understanding of how crustal growth processes occur in an active margin setting.

\section{Tectonic setting of the Philippine archipelago}

The convergence of the Sundaland-Eurasian margin with the Philippine Sea Plate resulted in the different features that comprise the Philippine archipelago. These include magmatic arcs, subduction zones, collision zones and marginal basins. Based on seismicity and volcanism, the Philippine archipelago is divided into the seismically active Philippine Mobile Belt and the aseismic Palawan microcontinental block. The Philippines is bounded on the east by the westward-dipping East Luzon Trough-Philippine Trench along which the Philippine Sea Plate is obliquely subducting. NUVEL-1 measurements show that the Philippine Sea Plate, in the region northeast of Luzon, is moving northwest at a rate of approximately $7 \mathrm{~cm}$ per year. But southeast of Mindanao, the plate motion increases to $\sim 9 \mathrm{~cm}$ per year (Bautista et al., 2001). Several marginal basins are found on the western portion of the archipelago. These include the South China Sea, Sulu Sea and Celebes Sea basins, which are subducting along the east-dipping Manila-Negros-Sulu-Cotabato trenches (Figure 1). The different ophiolite complexes, which can be found in various parts of the country, are believed to have originated from the marginal basins or their ancient counterparts surrounding the archipelago. The magmatic arcs associated with the subduction zones as well as the different ophiolite complexes are discussed in the succeeding sections. Excess stress resulting from the subduction of oceanic crusts along these subduction zones is absorbed by the Philippine Fault Zone and other related fault structures (Fitch, 1972).

\section{Magmatic arcs}

The Philippine island arc is built on oceanic crust, which had been modified by several episodes of magmatism (Figure 2a). Arc magmatic activity that characterized the evolution of the Philippines served to thicken the crust of this island arc system.

The earliest volcanic activity recorded in arc volcanic rocks from the Philippine Mobile Belt commenced during the Cretaceous time (Wolfe, 1981; Deschamps and Lallemand, 2002). A record of this volcanic activity is preserved in arc rocks from Cebu, which yielded a late Early Cretaceous age $(\sim 108 \pm 1 \mathrm{Ma})$ (Walther et al., 1981). Evidence for this activity is also preserved in Catanduanes Island where an andesite sample gave a K-Ar age of 121.09 $\pm 2.61 \mathrm{Ma}$ (David, 1994). There is also a record of magmatism preserved in the Luzon Central Cordilleran region during the Late Cretaceous period (K-Ar dating of schist sample: 82.6 \pm 20.6 m.y.) (Wolfe, 1981). Ringenbach (1992) has also reported an Upper Cretaceous age (Cam- 


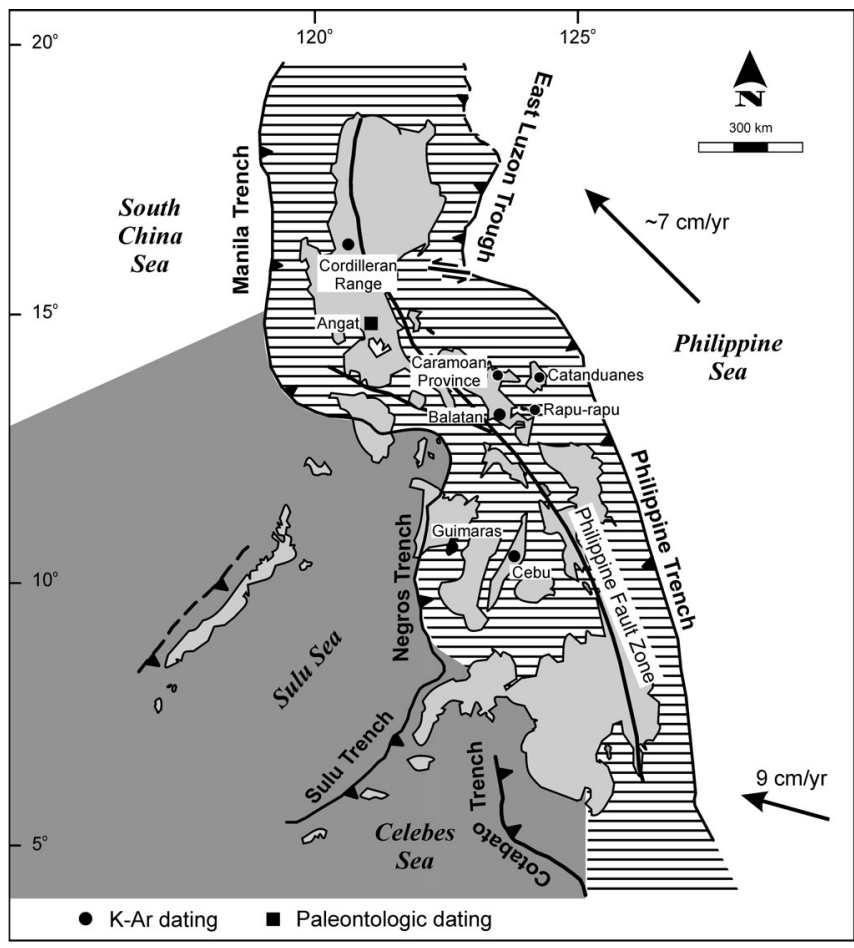

Figure 1 Map of the Philippines showing its general tectonic features. The Philippines is divided into the seismically active Philippine Mobile Belt (horizontally lined pattern) and the aseismic Palawan microcontinental block (dark gray shaded area). The rate and direction of convergence as determined from the GPS measurements (adopted from Bautista et al., 2001) is indicated by the vectors. Areas from which Cretaceous magmatic ages were determined (using $\mathrm{K}$-Ar or Ar-Ar dating = filled circle; using paleontologic dating = filled square) are also shown on the map (Walther et al., 1981; Wolfe, 1981; David, 1994; David et al., 1996; 1997).
panian-Maastrichtian) for the pelagic foraminifera found in volcaniclastic sediments in Angat, Southern Sierra Madre (Figure 1). The subduction of the Philippine Sea Plate along the proto-East Luzon Trough is believed to be responsible for this magmatic episode. This is consistent with the existence of a well-developed accretionary prism, which cannot be attributed to the rejuvenated, present-day East Luzon Trough (Balce et al., 1976; Yumul et al., 2003c).

A Late Cretaceous volcanic arc sequence was mapped in the Caramoan region in southeastern Luzon. ${ }^{40} \mathrm{Ar}-{ }^{39} \mathrm{Ar}$ dating of amphibole separates from a basaltic lava flow sample yielded an age of $91.1 \pm 0.5 \mathrm{Ma}$ (David et al., 1997). Cretaceous magmatism is also recorded in Rapu-rapu where diorite intruding the ultramafic rocks yielded a 77.1 $\pm 4.6 \mathrm{Ma}$ age (David et al., 1996). Further south of that, three magmatic episodes have been recognized in the Southeastern Luzon volcanic arc. The oldest magmatism is recorded at $68.6 \mathrm{Ma}$ from Balatan, which is in the central portion of the Southeastern Luzon volcanic arc. This age was based on the result of a K-Ar dating on a dioritic sample (Japan International Cooperation Agency-Metal Mining Agency of Japan, 1999). Andal (2002) suggested that this magmatic episode might be attributed to the subduction of the northern margin of the Indo-Australian Plate below the Philippine Sea Plate. In Central Philippines, the oldest dated rocks are found in Guimaras Island with an age of $59 \pm 2 \mathrm{Ma}$ (Wolfe, 1981) (Figure 1).

The next most significant period of magmatism is represented by the Paleogene (Paleocene-Oligocene) and Neogene magmatic belts (Figure 2a) (Wolfe, 1981; Bureau of Mines and Geosciences, 1982; Yumul et al., 2003b). Most of the Paleogene magmatic belts are found in eastern Philippines (e.g. Sierra Madre, Bicol, SamarLeyte and eastern Mindanao). Volcanism along eastern Philippines, from Bicol to Leyte, is mostly related to the westward subduction of the Philippine Sea Plate along the Philippine Trench (Divis, 1980). Oligo-Miocene magmatism, which are significant because of the gold deposits in the Philippines that are related to these intrusions, are represented by rocks in the Luzon Central Cordillera, eastern Negros - western Panay, Eastern Mindanao and Cotabato (Figure 2a) (Mitchell and Leach, 1991; Yumul et al., 2003a).

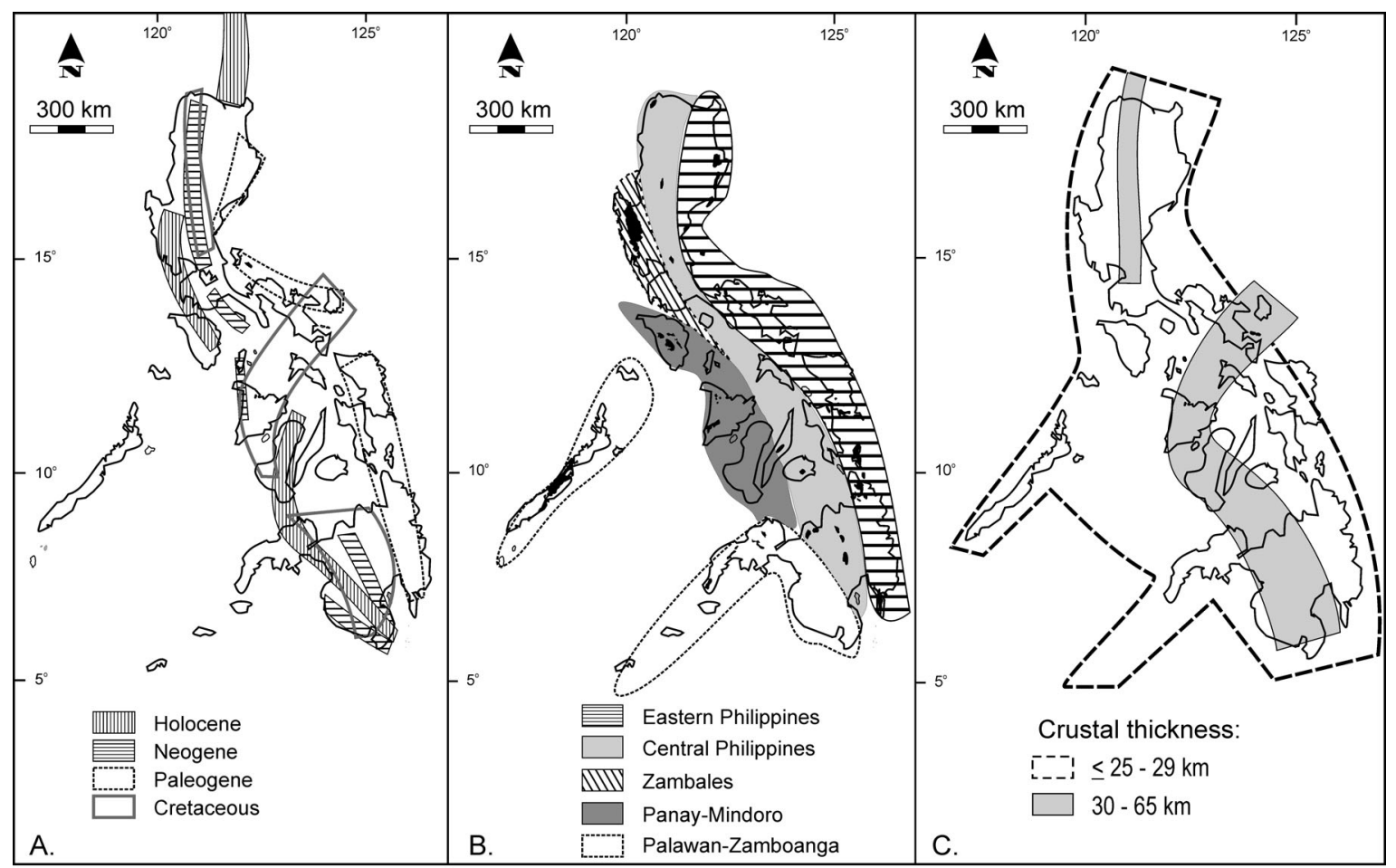

Figure 2 A-Map showing the ancient and modern magmatic arcs (modified from Aurelio, 2000; Yumul et al., 2003b). B-Map showing the different ophiolite/ophiolitic complexes that comprise the Philippine archipelago (Yumul, 2003). C-Map summarizing the thickness of the crust in various parts of the Philippines. Area enclosed in dashed lines corresponds to crustal thickness of $\sim 15$ to 29 kilometers. Gray shaded areas indicate crustal thickness from 30 to 65 kilometers (modified from Dimalanta and Yumul, 2003). See text for details. 
The Neogene magmatic arc from Tablas-Western Panay, which was interpreted by Mitchell and Leach (1991) to be a continuation of the Miocene Luzon arc, is deemed to be associated with the subduction of the South China Sea plate along the Manila-Negros Trench. In Cotabato, the Neogene magmatic belt is attributed to subduction of the Celebes Sea plate along the Cotabato Trench. Sajona (1995) proposed that volcanoes in central Mindanao, which cannot be attributed to any active subduction zone, may be explained as the products of partial melting of a detached slab beneath Mindanao.

Holocene magmatic belts are noted north of Luzon in the Batanes islands, Zambales-Bataan-Mindoro and Negros-Zamboanga-Western Mindanao (Figure 2a). The Holocene volcanism in Luzon is attributed to the subduction of the South China Sea oceanic lithosphere along the east-dipping Manila Trench (Yumul et al., 2003b). The volcanoes in eastern Negros have been proposed to be related to the subduction of the Sulu Sea basin along the Negros Trench (Mitchell and Leach, 1991). The Zamboanga-Western Mindanao arc is explained by subduction along the Sulu Trench (Aurelio, 2000).

These different episodes of magmatic activities commencing from the Cretaceous to Recent have produced a considerable volume of materials $\left(1.85 \times 10^{6} \pm 256,000 \mathrm{~km}^{3}\right)$. This translates to arc magmatic addition rates ranging from 30 to $95 \mathrm{~km}^{3} / \mathrm{km} / \mathrm{m}$.y. (Dimalanta and Yumul, 2003).

\section{Ophiolites and ophiolitic complexes}

Another mechanism that results into crustal addition, aside from arc magmatism, is the emplacement of ophiolites (Figure 3a). The presence of ophiolite and ophiolitic complexes has been reported by workers in various parts of the Philippine archipelago (e.g. Balce et al., 1976; Yumul et al., 1997; Tamayo, 2001; Dimalanta and Yumul, 2003). These exposed oceanic lithospheres make up a large part of the basement lithologies in these areas. Ophiolite complexes are believed to have been emplaced and accreted through onramping, upwedging, compression and faulting (Figure 3a) (e.g. Moores, 1982; Cannat, 1993; Hacker et al., 1996).

Balce et al. (1976) presented a zonation of ophiolite complexes based on the geographic distribution of these ophiolite units. Recent data, however, has led to the grouping of the ophiolites, on the basis of their ages as well as other characteristic features (e.g. presence of associated metamorphic sole; related to mélanges; manner of emplacement mechanism). The ophiolites are grouped into the following belts: Eastern Philippines, Central Philippines, Zambales, Panay-Mindoro, Palawan-Zamboanga (Figure 2b). This latest zonation suggests a progressive younging of the ophiolites in a westward direction (Yumul, 2003).

Despite the presence of numerous ophiolites and ophiolitic complexes in different parts of the archipelago, the volume of material resulting from the emplacement of these ophiolites $(724,000 \pm$ $43850 \mathrm{~km}^{3}$ ) is considerably less than the amount produced during arc magmatism $\left(1.85 \times 10^{6} \pm 256,000 \mathrm{~km}^{3}\right)$ (Dimalanta and Yumul, 2003). This is understandable considering that not all of the materials become accreted or emplaced. Some crustal subtraction takes place when a certain portion of the materials becomes destroyed or lost as a result of subduction, tectonic erosion or subduction kneading (e.g. Charvet and Ogawa, 1994; Clift et al., 2003).

The simplified computation of the volume of material related to ophiolite and ophiolitic complexes yielded ophiolite accretion rates ranging from 2 to $19 \mathrm{~km} 3 / \mathrm{km} / \mathrm{m}$.y. (Dimalanta and Yumul, 2003). These rates are lower compared to the few rates that are available elsewhere. Godfrey and Klemperer (1998) derived an ophiolite accretion rate of $50 \mathrm{~km} / \mathrm{km} / \mathrm{m}$.y. for the Great Valley ophiolite in California. Although arc magmatic processes dominate crustal growth in the Philippines, present available data demonstrate the critical role played by amagmatic crustal growth processes, that is, the accretion of ophiolites. This is made more significant considering the fact that the Philippine island arc system is made up of several collision and suture zones. These areas are, almost always, characterized by the presence of ophiolites and, to a certain extent, mélanges.

\section{Crustal growth by magmatic and tectonic processes}

Available field, geophysical (e.g. seismicity, gravity, seismic refraction) and geochemical data (e.g. $\mathrm{CaO}_{6.0}$ and $\mathrm{Na}_{2} \mathrm{O}_{6.0}$ ) were utilized to estimate crustal thickness in various parts of the Philippine archipelago. The resulting values were subsequently used to obtain arc magmatic addition as well as ophiolite accretion rates. This kind of work had not been done previously for the entire Philippines. The results reveal that certain portions of the Philippines are underlain by thickened crust $(>30 \mathrm{~km}$ ) (Dimalanta and Yumul, 2003). From the observed crustal thicknesses, this paper presents and examines the various mechanisms responsible for the thickening of the crust in the archipelago.

Figure 2c shows that a zone of thickened crust characterizes the Luzon Central Cordillera region. The oldest magmatic activity in this region began during the Late Cretaceous period. Substantial thickening of the crust was brought about by subsequent magmatic episodes from the Paleocene to Upper Miocene, which are recorded among the various sedimentary and igneous rocks in this region (Dimalanta, 1996). Such multiple phases of magmatism concentrated along linear belts corresponding to magmatic arcs can explain

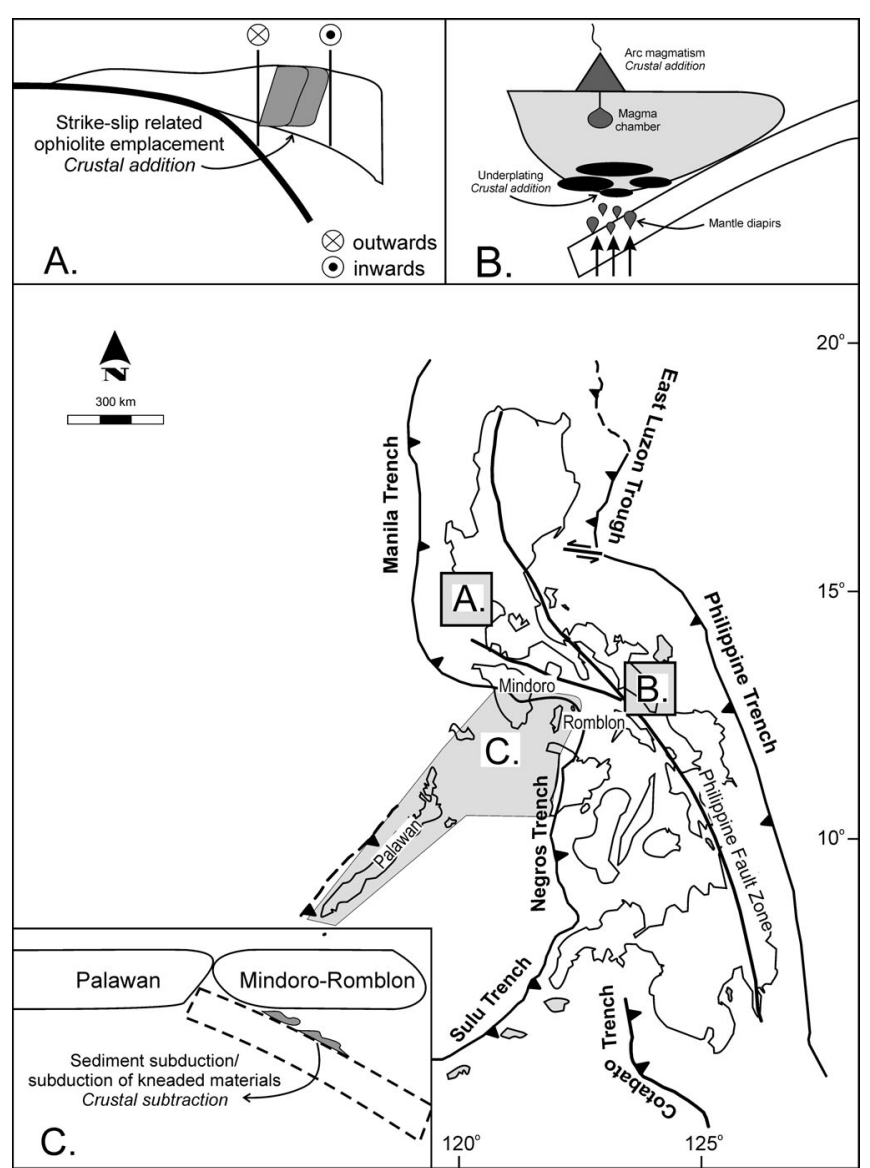

Figure 3 Schematic diagram showing crustal addition by different mechanisms. A-Emplacement of ophiolite by strike-slip faulting (e.g. Zambales ophiolite) leads to the addition of materials. B-The significantly thickened crust in Bicol, southeastern Luzon may be accounted for by numerous episodes of arc magmatism in the region. C-The collision between the Palawan microcontinental block and the Philippine Mobile Belt did not result into crustal thickening. Further work needs to be done in order to determine whether the absence of crustal thickening is due to crustal subtraction such as subduction erosion or other related process. 
why there is a thickening of the crust in this part of the Philippines. This mechanism may also account for the thickened crust that can be observed in other parts of the Philippines like the central Mindanao region.

The significantly thickened crust in Bicol, southeastern Luzon may be accounted for by the numerous episodes of arc magmatism, both ancient and recent, which the region had experienced (Figure $3 b)$. This area is also characterized by the presence of several ophiolite complexes. The emplacement of these ophiolite complexes has further served to increase the thickness of the crust in this part of the archipelago.

It is interesting to note that in the zonation of the Philippines based on crustal thickness, central Philippines (i.e. Negros, Panay, Cebu and Bohol) is shown to be made up of thick crust (30-65 km) (Figure 2c). One of the magmatic belts passes through this region. The islands are also characterized by the presence of ophiolite suites. In eastern Central Philippines, Leyte is characterized by Neogene volcanism but no ancient magmatic activity has been reported for the island. Hence, the crust here is only less than 30 kilometers thick. Although Leyte is also floored by an ophiolite basement, this has not caused a substantial increase in the thickness of the crust.

It would, thus, appear that crustal thickening in the Philippines is the result of the various episodes of arc magmatism occurring in almost the same region or belt, which modified the crust. In addition, the emplacement of ophiolites through various mechanisms has put in a considerable amount of material to cause crustal thickening. However, based on present available rates, it is apparent that the

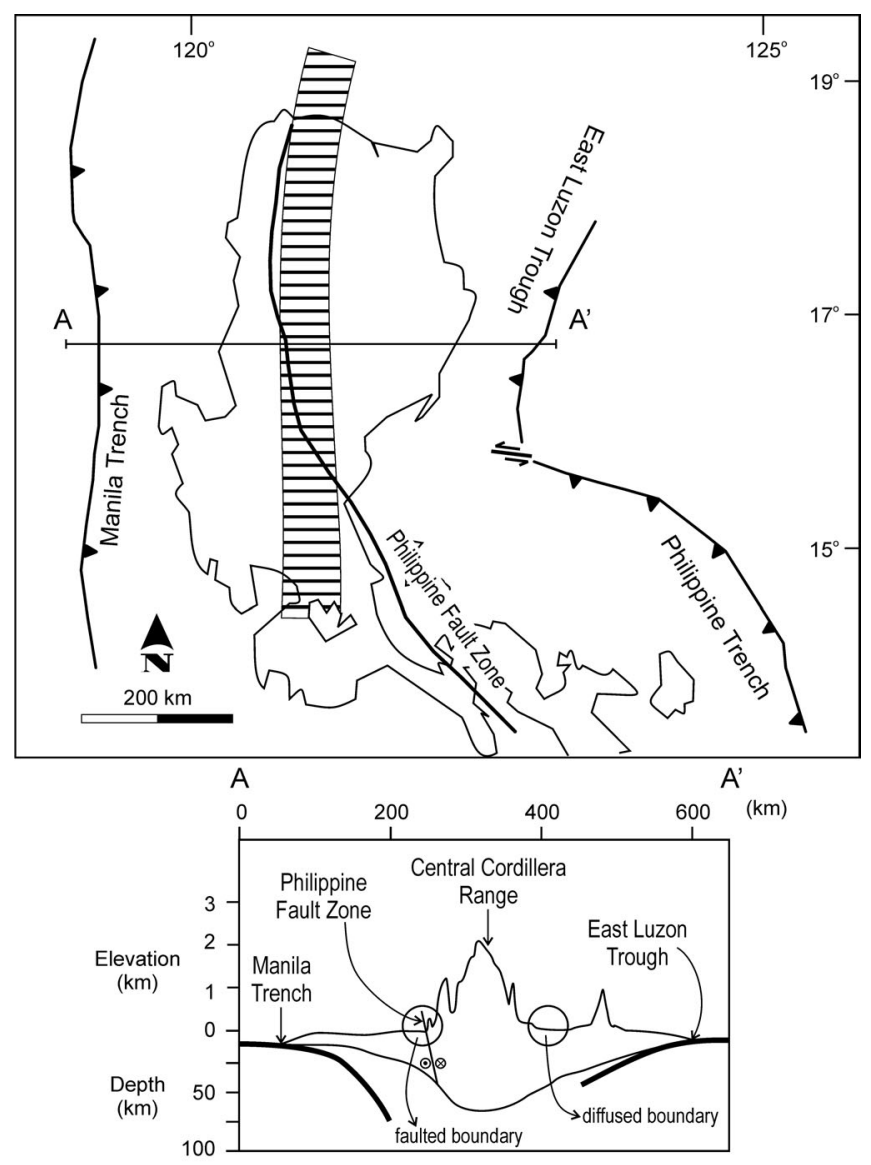

Figure 4 Schematic diagram showing the boundary between the thin and thick (horizontally lined area) crustal region in Luzon which, in some places, coincides with major faults. In places where no physical boundary is observed, the interplay of various magmatic, structural and sedimentation processes causes the boundary to be diffused and not readily discernible. The Central Cordillera Range corresponds to the volcanic/magmatic arc in Northern Luzon. addition of materials by arc magmatism is more substantial compared to those added during the accretion and emplacement of ophiolites.

The boundary between the thick and thin crustal regions coincides with recognized sutures (e.g. Siayan-Sindangan Suture Zone in western Mindanao) or major faults (e.g. the Philippine Fault Zone) in some places (Figure 4). In areas where a physical boundary between the thin and thick crustal regions is not observed, this might be attributed to the complex history involving magmatic, structural and sedimentation processes which makes the boundary not readily observable. This is a subject that can be looked into in future research work.

The collision between the Palawan microcontinental block and the Philippine Mobile Belt during the Early Miocene is one of the more significant events in the evolution of the Philippines (Bellon and Yumul, 2000). Hence, it may be worthwhile to consider whether the collision event had any effect on the thickening of the crust. In the crustal thickness zonation map, the Mindoro-Romblon region, which is supposedly the site of collision (Yumul et al., 2003c), does not show any significant thickening of the crust. The material being "crumpled" as a result of the collision has not sufficiently thickened or stacked up to cause a significant increase in the thickness of the crust in the area surrounding the collision zone. Current studies are being undertaken to investigate what processes are responsible for this result. However, some initial models to explain the absence of crustal thickening from collision are proposed here. This could be due to the fact that although the collision is still in progress, the resulting crustal thickening has not been readily registered. Another possibility is that the plates that are colliding are initially thin, thus, although considerable thickening of the collided portions occurred, with respect to the surrounding plates, they do not manifest anomalous thickness. Although accretion can result from collision, mechanisms such as delamination, subduction erosion and other related processes might also explain the observed result (Figure 3c). This will have to be addressed by future work.

\section{Conclusions}

The most recent estimates of arc magmatic addition rates in the Philippines reveal values from 25 to $60 \mathrm{~km}^{3} / \mathrm{km} / \mathrm{m}$.y. Ophiolite accretion rates have been estimated to range from 2 to 19 $\mathrm{km}^{3} / \mathrm{km} / \mathrm{m}$.y., which are considerably higher compared to rates obtained elsewhere. From the volumes of crustal material produced by arc magmatism, it would seem that crustal growth in the Philippines has been dominated by arc magmatism. However, contributions from the emplacement and accretion of ophiolites are quite significant. The combination of these processes might also explain the occurrence of thickened crust in certain portions of the archipelago (i.e. Luzon Central Cordillera and the Bicol-Panay-Masbate areas). The "crumpling" effect caused by the collision event between the Palawan microcontinental block and the Philippine Mobile Belt has not resulted in thickening of the collided crusts. The manner in which island arcs evolved, as presented here, through magmatic and amagmatic processes may help us understand their ultimate fate of being accreted to the continents.

\section{Acknowledgements}

The University of the Philippines-National Institute of Geological Sciences research grants to CBD and GPY are acknowledged. Most of the work on ophiolites and arc volcanoes were funded by the Philippine Department of Science and Technology and the Philippine Council for Industry and Energy Research and Development. Discussions with members of the Rushurgent Working Group are acknowledged. 


\section{References}

Andal, E.S., 2002, Geological and geochemical characterization of the PlioPleistocene to Recent volcanic rocks of the Southeastern Luzon Volcanic Arc Chain: Implications to arc evolution: M.Sc. Thesis, University of the Philippines, $154 \mathrm{pp}$.

Aurelio, M.A., 2000, Tectonics of the Philippines revisited: Journal of the Geological Society of the Philippines, v. 55, 119-184.

Balce, G.R., Alcantara, A.P., Morante, E.M. and Almogela, D.H., 1976, Tectonic framework of the Philippine Archipelago (A review): Bureau of Mines, Manila, Internal Report, 67pp.

Barretto, J.A.L., Dimalanta, C.B. and Yumul, G.P.Jr., 2000, Gravity variations along the Southeast Bohol Ophiolite Complex (SEBOC), Central Philippines: Implications on ophiolite emplacement: The Island Arc, v. 9, pp. 575-583.

Bautista, B.C., Bautista, M.L.P., Oike, K., Wu, F.T. and Punongbayan, R.S., 2001, A new insight on the geometry of subducting slabs in northern Luzon, Philippines: Tectonophysics, v. 339, pp. 279-310.

Bellon, H. and Yumul, G.P.Jr., 2000, Mio-Pliocene magmatism in the Baguio Mining District (Luzon, Philippines): age clues to its geodynamic setting: Comptes Rendus Academie Science, v. 331, pp. 295-302.

Bureau of Mines and Geosciences, 1982, Geology and Mineral Resources of the Philippines: Manila, Ministry of Natural Resources, 406pp.

Cannat, M., 1993, Emplacement of mantle rocks in the seafloor at Mid-Ocean Ridges: Journal of Geophysical Research, v. 98, pp. 4163-4172.

Charvet, J. and Ogawa, Y., 1994, Arc-trench tectonics, in Hancock, P.L., ed, Continental Deformation: Oxford, Pergamon Press, pp. 180-199.

Clift, P.D., Vannucchi, P. and Draut, A.E., 2003, Tectonic erosion, subduction accretion and arc collision as controls on the growth of the continental crust: Geophysical Research Abstracts, v. 5, pp. 01464-01465.

Condie, K.C., 1998, Episodic continental growth and supercontinents: a mantle avalanche connection? Earth and Planetary Science Letters, v. 163, pp. 97-108.

David, S.D.Jr., 1994, Geologie du Sud-Est de Luzon - Contributions a l'etude geodynamique ante-Neogene de la Ceinture Mobile Est Philippine: These de doctorat, Universite de Nice-Sophia Antipolis, Nice, France, $352 \mathrm{pp}$.

David, S.D.Jr., Stephan, J.-F., Delteil, J., Bellon, H. and Sajona, F.G., 1996, Geology, geochemistry, geochronology and structures of the ophiolites in Southeastern Luzon, Philippines: Journal of the Geological Society of the Philippines, v. 51, 115-129.

David, S.D.Jr., Stephan, J.-F., Delteil, J., Msller, C., Butterlin, J., Bellon, H. and Billedo, E., 1997, Geology and tectonic history of Southeastern Luzon, Philippines: Journal of Asian Earth Sciences, v. 15, 435-452.

Deschamps, A. and Lallemand, S., 2002, The West Philippine Basin: An Eocene to early Oligocene back arc basin opened between two opposed subduction zones: Journal of Geophysical Research, v. 107, pp. EPM 1$1-1-24$.

Dewey, J.F. and Windley, B.F., 1981, Growth and differentiation of the continental crust: Philosophical Transactions of the Royal Society of London, v. A301, pp. 189-206.

Dimalanta, C.B., 1996, Magnetic signatures of lithologic variation, fault structures and hydrothermal mineralization: An example from the Baguio Mineral District, Luzon, Philippines: Journal of Southeast Asian Earth Sciences, v. 14, pp. 1-10.

Dimalanta, C.B. and Yumul, G.P.Jr., 2003, Magmatic and amagmatic contributions to crustal growth of an island arc system: The Philippine example: International Geology Review, 45, 922-935.

Divis, A.F., 1980, The petrology and tectonics of recent volcanism in the Central Philippine Island, in Hayes, D.E., ed, The tectonic and geologic evolution of Southeast Asian Seas and Islands: Washington, D.C., American Geophysical Union, pp. 127-144.

Fitch, T.J., 1972, Plate convergence, transcurrent faults and internal deformation adjacent to Southeast Asia and the Western Pacific: Journal of Geophysical Research, v. 77, pp. 4432-4460.

Godfrey, N.J. and Klemperer, S.L., 1998, Ophiolitic basement to a forearc basin and implications for continental growth: The Coast Range/Great Valley ophiolite, California: Tectonics, v. 17, pp. 558-570.

Hacker, B.R., Mosenfelder, S.C. and Gnos, E., 1996, Rapid emplacement of the Oman ophiolite: thermal and geochronologic constraints: Tectonics, v. $15,1230-1243$.

Japan International Cooperation Agency - Metal Mining Agency of Japan, 1999, Report on Regional Survey for Mineral Resource in the Bicol Area: Tokyo.

Mitchell, A.H.G. and Leach, T.M., 1991, Epithermal Gold in the Philippines: Island arc metallogenesis, geothermal systems and geology: London, Academic Press Limited, 457pp.
Moores, E.M., 1982, Origin and emplacement of ophiolites: Reviews of Geophysics and Space Physics, v. 20, pp. 735-760.

Rapp, R.P. and Watson, E.B., 1995, Dehydration melting of metabasalt at 832 kbar: Implications for continental growth and crust-mantle recycling: Journal of Petrology, v. 36, pp. 891-931.

Reymer, A. and Schubert, G., 1984, Phanerozoic addition rates to the continental crust and crustal growth: Tectonics, v. 3, pp. 63-77.

Ringenbach, J.C., 1992, La faille Philippine et les chaines en decrochement associees (centre et nord de Luzon): Evolution Cenozoique et cinematique des deformations Quaternaries: These de doctorat, Universite de Nice-Sophia Antipolis, Nice, France, 336 pp.

Rudnick, R.L., 1995, Making continental crust: Nature, v. 378, pp. 571-578.

Sajona, F.G., 1995, Slab melting in subduction and collision zones: geochemistry, geochronology and petrology of Plio-Quaternary magmatism of Mindanao (Philippines): These de doctorat, Universite de Brest Occidentale, Brest, France, 204 pp.

Tamayo, R.A. Jr., 2001, Caractérisation pétrologique et géochimique, origines et évolutions géodynamiques des ophiolites des Philippines: These de Doctorat, Universite de Bretagne Occidantale, France, 318pp.

Walther, H.W., Foerster, H., Harre, W., Kreuzer, H., Lenz, H., Mueller, P. and Raschka, H., 1981, Early Cretaceous porphyry copper mineralization on Cebu Island, Philippines, dated with $\mathrm{K}-\mathrm{Ar}$ and $\mathrm{Rb}-\mathrm{Sr}$ methods: Geologisches Jahrbuch Reihe D, v. 48, pp. 21-35.

Wilson, M., 1994, Igneous Petrogenesis: A Global Tectonic Approach: London, Chapman and Hall, $466 \mathrm{pp}$.

Wolfe, J.A., 1981, Philippine geochronology: Journal of the Geological Society of the Philippines, v. 35, pp. 1-30.

Yumul, G.P.Jr., 2003, The Cretaceous Southeast Bohol Ophiolite Complex, Central Philippines: a highly disaggregated supra-subduction zone ophiolite: Journal of Asian Earth Sciences, v. 21, pp. 957-965.

Yumul, G.P.Jr, Balce, G.R., Dimalanta, C.B. and Datuin, R.T., 1997, Distribution, geochemistry and mineralization potentials of Philippine ophiolite and ophiolitic sequences: Ofioliti, v. 22, pp. 47-56.

Yumul, G.P.Jr, Dimalanta, C.B, Maglambayan, V.B. and Tamayo, R.A.Jr., 2003a, Mineralization controls in island arc settings: Insights from Philippine metallic deposits: Gondwana Research, v. 767-776.

Yumul, G.P.Jr, Dimalanta, C.B, Tamayo, R.A.Jr. and Bellon, H., 2003b, Silicic arc volcanism in Central Luzon, the Philippines: Characterization of its space, time and geochemical relationship: The Island Arc, v. 12, pp. 207-218.

Yumul, G.P.Jr, Dimalanta, C.B, Tamayo, R.A.Jr. and Maury, R.C., 2003c, Collision, subduction and accretion events in the Philippines: A synthesis: The Island Arc, v. 12, pp. 77-91.

C.B. Dimalanta is presently an Assistant Professor at the National Institute of Geological Sciences, University of the Philippines, Diliman, Quezon City, Philippines 1101. She obtained her D. Sc. degree from the Ocean Research Institute, University of Tokyo in September 2001. Her research interests include the use of gravity and seismic data to determine the crustal thickness of island arcs.

\section{G.P. Yumul, Jr. is a Professor at the} National Institute of Geological Sciences, University of the Philippines, Diliman, Quezon City, Philippines 1101. He is also currently the Executive Director of the Philippine Council for Industry and Energy Research and Development of the Philippine Department of Science and Technology. He obtained his D.Sc. degree from the Geological Institute, University of Tokyo in 1990. Most of his work deals with the geochemistry and petrology of ophiolites and adakites as well as the tectonics of the Philippines.
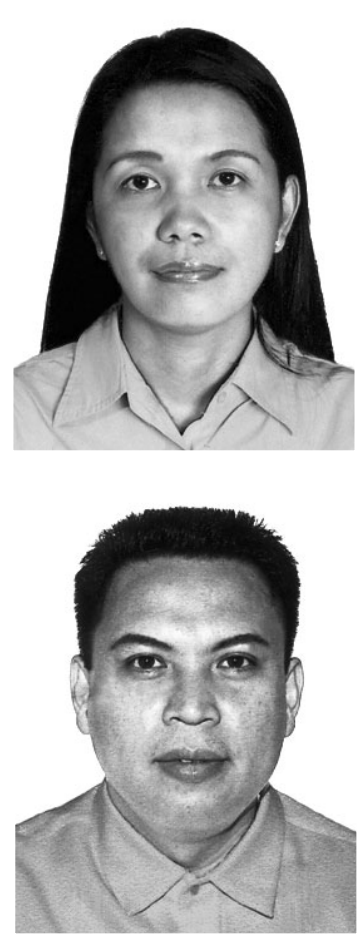